\title{
Latex and silicon allergy related to cerebrospinal shunt hardware: a review
}

\author{
Hernando Alvis-Miranda ${ }^{1}$, Gabriel Alcala-Cerra ${ }^{2}$, Sandra Milena \\ Castellar-Leones ${ }^{1}$, Hector Farid Escorcia ${ }^{3}$, Luis Rafael Moscote-Salazar ${ }^{1}$
}

${ }^{1}$ University of Cartagena, ${ }^{2}$ Resident of Neurosurgery, ${ }^{3}$ Hospital CARI Barranquilla

\begin{abstract}
A less frequent complications of shunt systems ventriculoperitoneal used for the management of hydrocephalus is the allergy materials which usually are built, silicone and latex. Patients undergoing multiple changes device may be at risk of developing high rejection to materials. Differential diagnosis should be done with infections and obstructions, usual causes of dysfunction. We present a review updated literature focused neurosurgeon.
\end{abstract}

Key words: silicone allergy, shunt malfuncion, hydrocephalus

\section{Introduction}

The biomaterials used in the central nervous system include silicone, lipids, natural polymers and synthetic polymers in various forms based on their applications (1).

Biocompatibility of implants in humans has been classified as "inert", "tolerated", and "bioactive" (2). Today is well known that silicone and latex are not inert materials, so the body can react in different ways respect to them.

The cerebrospinal fluid (CSF) shunts typically consist of a proximal catheter, which runs from the cerebral ventricles' subarachnoid spaces to a valve that connects to a distal catheter and regulates the drainage of CSF (1). The distal catheter is a long thin silicone tube that is placed subcutaneously and terminates in a distal body cavity where the CSF can be reabsorbed into the body (3-5). In shunttreated patients, catheter-induced complications account for up to $70 \%$ of all hardware failures (2), the remainder are due to conditions like allergy or hypersensitivity to latex, and more rarely to silicone, this has now become a worrying health concern, that not only affects patients with multiple surgical interventions, but health care workers too (6). The aim of this review is to remember the clinical relevance of CSF shunt related hypersensitivity and allergy, and management repercussions in these circumstances.

\section{Epidemiology}

\section{Silicon:}

The incidence of silicone ventricular shunt allergies is rare. Evidence of silicone allergy may have been origin for certain complications in breast and joint implants is present since 1984, when Gower et al. (7) using electron microscopy, postulated that a small subset of shunt malfunctions could be attributed to silicone allergy. In 1989, Snow and Kossovsky (8), studied the clinical and pathological findings in 29 patients who underwent surgical procedures to revise malfunctioning ventriculoperitoneal 
shunts. A pathologist independently examined the shunt hardware removed, and was observed that three patients had evidence of some hypersensitivity reaction due to the shunt hardware (multiple eosinophils and giant cells in tissue enveloping shunt hardware). In 1992, Goldblum, et al. (9) reported two patients who showed severe reactions to ventriculoperitoneal (VP) shunts, using ELISA they demonstrated that patients had increased quantities of serum IgG, indicating an immunemediated reaction. In 1994, Jimenez et al. (10) reported three hydrocephalic patients who developed a clinically heterogeneous entity with an allergic rejection of their silicone ventriculoperitoneal shunts. Clinically, the presentation was indicative of shunt infection, but in all three patients there was a sterile CSF. Patients had recurrent skin breakdowns over the shunt tract, subsequent infections and development of fungating granulomas. The treatment included the replacement in one patient the silicone shunt material to polyurethane plus inmunossupression and in the other patients, the original shunt system was removed without a replacement. In 1999 a single case of bowel perforation caused by silicone shunt allergy was reported (11).

\section{Latex:}

When allergies to medical biomaterial do occur, the causative agent is often latex (12, 13). Case reports of allergic reactions to latex proteins have been described with various products from 1927 (14, 15), but since 1979 (16), IgE-mediated allergy to latex has drawn much attention.

Latex sensitization remains the second most common cause of anaphylaxis (16.9\%), during anesthesia in the general population $(17,18)$. Children with myelomeningocele or spina bifida (SB) and urogenital abnormalities have high incidence of IgE-mediated allergic reactions, probably due to a high degree of exposure to latex products through repeated surgical procedures, catheterization, and implant of latex-containing material (19, 20). Particularly, patients with SB have more severe and unexpected allergic reactions, linked with surgical procedures $(21,22)$. Patients with sensitization have a 500 times greater risk of serious reactions related to latex intraoperatively than that of the general population (23).

Nieto et al (24), in their 100 patient series with spina bifida, found a $29 \%$ prevalence of sensitization to latex; among patients with a V-P shunt, sensitization to latex was present in 36\%, but there was not a single case of sensitization among those patients without it. They tried to identify those factors that may have a causal or predisposing role in the process of sensitization, the analysis disclosed many significant variables, but closely linked. As age increases, so does the rate of sensitization, but also an increase in the number of surgical procedures and, in the number of all diagnostic and therapeutic procedures, as well as in the absolute levels of serum total IgE. Logistic regression analysis selected the variable "number of operations" as the one that most contributed to the process of sensitization. Three other variables (serum total $\operatorname{IgE}$ levels, presence of a V-P shunt, and personal antecedents of atopic disease in this order) were synergistic and included to build the most parsimonious model. V-P shunt devices are made of silicone and do not contain latex, but has been suggested its co-adjuvant role as a foreign body in the process of sensitization. 
Kattan et al. (25) reported the results of fifty-nine patients, aged 1-20 years, with SB that were evaluated by a questionnaire on type of latex reactions; family and personal history of other allergic disorders, such as asthma, rhinitis, and urticaria; type and number of surgical procedures; and frequency of bladder catheterization and manipulation with latex materials. Confirmation of latex sensitivity was measured by skin prick test (SPT), CAP test, and latex skin challenge. They found allergy to latex in $25 \%$ of the study group. There was a significant variation in allergic reaction by sex (males $42 \%$, females $12 \%$ ) $(\mathrm{P}<0.01)$, use of catheters (yes $38 \%$, no $13 \%)(\mathrm{P}<0.05)$, and urologic surgery (yes $60 \%$, no $18 \%)(\mathrm{P}<0.01)$. The number of surgical procedures, age of patient, and V-P shunt were not significantly related to allergic reactions, they have no explanation for the difference in their patients, other than the possibility of genetic differences and, perhaps, extra precautions taken by surgeons in minimizing the use of latex articles in such patients. Tangsinmankong et al. (26) reported a case of a patient with congenital hydrocephalus and a V-P shunt, who developed CSF eosinophilia associated with latex allergy and shunt malfunction.

\section{Latex allergy}

Latex is an emulsion product from Hevea brasiliensis trees (27). Today nearly all commercial natural rubber comes from latex of those trees, commercially grown in a number of tropical countries. Another source of latex is the guayule bush (Parthenium argentatum) (28). Interestingly the latex from the guayule bush does not appear to contain proteins cross-reactive with the allergens of Hevea latex (29). Other closely related materials that have been reported to be potentially cross-reactive with Hevea latex are guttapercha and gutta-balata from Sapotaceae trees (30). Natural latex is widely used in the medical field (e.g., gloves, catheters, tubing, syringes, tourniquets), but also in everyday life (pacifiers, balloons, children's toys, hats and slippers pools, mattresses, shoes, clothes, condoms). Latex allergy is a type I allergy, i.e., IgE mediated. Patients are often associated with food allergy focusing on the fruit (31), especially banana (15). Crossed latex and food allergy constitutes a phenomenon of particular concern because the list of food allergens probably involved is steadily increasing. The prevalence of latex allergy is well known in certain risk groups such as those patients with multiple surgical interventions and among health care professionals $(31,32)$.

Latex proteins are numerous, and allergy to latex is related to a complex mixture of proteins (33-35). The risk of anaphylaxis is suggested by history of atopic diseases, such as asthma, allergic rhinitis, food allergy, and urticaria, or previous allergic symptoms on exposure to latex-containing materials (25). A series of distinct proteins occurring at either high (Heb b 6) or very low concentration (Hev b 1-5, Hev b 7-13) in the Hevea brasiliensis latex, have been identified as the IgE-binding allergens responsible for sensitization $(36,37)$. Children at risk for developing latex allergy, are those with allergy to bananas, kiwifruits, avocado, stone fruits, papaya, carrot, raw potato, tomato, chestnuts or peanuts, and those with history of a latex gloveassociated contact dermatitis (38).

\section{Silicon allergy}

Silicone rubber is a polymer biomaterial of the first generation (39), silicone is a group of synthetic polymers called 
organopolysiloxanes, with a molecular structure consisting of alternating silicon and oxygen atoms (40). Silicones can be fluids, gels, or solids (elastomers), depending on the length of the polymeric chain and the degree of crosslinking (10). CSF shunt devices are manufactured almost solely from medical grade silicone, owing to its chemical stability, minimal biological reactivity, low toxicity and noncarcinogenicity (41-43). Currently, silicone is used to make the following shunt components: catheters, access chambers, valve mechanisms, suture clamps and external valve housings (1). Silicones are used as encapsulants, adhesives, or coatings in medical devices. They are commonly used in cerebrospinal fluid shunts, intravenous tubing, drug delivery systems, cardiac valves, arthroplasty prostheses, and intraocular lens implants (10).

Allergy to shunting tube is rare (44), probably because of its high biocompatibility and low biological reactivity (45). Silicone has been considered safe and chemically inert, but immune mechanisms related to silicone materials have been proposed for some cases of obstruction of V-P shunts, because of inflammatory cells detected in the tubing lumen $(46,47)$, and for the evidence derived from patients and from animal experimental data to suggest that silicone can act as an antigen of a hapten complexed to self-proteins $(7-9,48-53)$ and could elicit inflammatory reactions, confirming that silicone is not inert biologically. Furthermore, has been demonstrated that silicone gel is a potent humoral or antibody adjuvant (54), and solid silicone implant can produce a similar type of hypersensitivity (55).

Implanted silicone prostheses and medical devices are associated with various local (mild fibrosis (56)) and systemic host inflammatory reactions, they have been associated with a form of autoimmune disease (51, 57). Heggers et al. (53) investigated the possibility of a cellular immune response to implanted silicone in an animal model. They observed histologically that the cellular response to polydimethylsiloxane in sensitized guinea pigs is consistent with a cellular immune reaction. Electron Microscopy and X-ray energy spectroscopy have demonstrated intracellular silicon in the intracellular machinery (Golgi apparatus, rough endoplasmic reticulum, and at both ends of cytoplasmic bridges) in macrophages and lymphocytes. Suggesting that those cells are processing a silicon-containing complex as an antigen (53). According to this theory, macrophages recruited to a foreign body reaction could release oxidizing free radicals capable of attacking the silicone present to liberate the irritating silica, but, this cannot be the sole mechanism responsible since fluid or gel silicone do not contain silica fillings and have also been shown to be irritants (53). Kossovsky et al. (48), also tested the hypothesis that silicones may evoke an immunologically mediated inflammatory reaction in a guinea pigs model, they found that animals stimulated with silicone-serum and those passively sensitized had four times greater palpable lesions at approximately $24 \mathrm{~h}$ compared to controls (saline solution)when challenged to different intradermal antigens (siliconehomologous serum, pure silicone, salinehomologous serum, and purified protein derivative), biopsies revealed a moderate to marked lymphocytic infiltrate. Control sites and naive animals showed only edema at the challenge sites, also suggesting that 
silicone-protein complexes are potentially immunogenic.

First cases of silicone allergy were encountered with the use of silicon stents $(58,59)$, the histological examination of the material embracing and occluding the tube, was founded abundance of eosinophils and giant cells, meaning an allergic reaction to the silicone material (44).

Unfortunately, the nature of the silicone antigen that elicits the immune response is not well known (9), another hypothesis to explain or justify the inflammatory reactions associated with silicone shunts is the electrostatic active internal surface of the silicone hardware, that gives the potential to increase the adherence of airborne particles to the shunt and facilitate a foreign tissue reaction by the body leading to a hypersensitivity condition $(7,60,61)$.

Apparently, the most frequent silicone allergy seems to be a type IV or delayedtype hypersensitivity reaction (9). This reaction is mediated by $\mathrm{T}$ cells and starts 2 to 7 days after the exposure. Interestingly, Hashimoto et al. (62) reported the case of a patient with an abdominal CSF pseudocyst that resulted from an allergic reaction to silicone. The patient underwent repair surgery of the meningomyelocele associated with the Chiari II malformation, and the V$P$ shunt was instituted at 6 months of age. A formation of the abdominal CSF pseudocyst and the consequent shunt malfunction were observed 40 days after the V-P shunt. An increase in the number of the peripheral eosinophils and serum immunoglobulin $\mathrm{E}$ ( $\operatorname{IgE})$, and an infiltration of eosinophils in the specimen harvested from the pseudocyst wall suggested an allergic reaction as the cause of the pseudocyst. A sixth operation to revise the V-P shunt was performed using the shunt system made of "extracted silicone", which was produced extracting the allergic substances. The serum IgE was normalized after surgery and the abdominal CSF pseudocyst has not recurred for 22 months.

\section{Clinical presentation}

In the case of silicon shunt allergy:

The allergic reactions typically occur through local reaction, silicone migration, or human autoimmune disease. The patient may present to the emergency room with symptoms of either indolent shunt infection due to irritability and low grade fever or shunt obstruction due to aggregation of the fenestrated catheter tip with eosinophils and giant cells (44). Can be present CSF eosinophilia $(44,63)$.

In the case of latex shunt allergy:

Overall, children at high risk for serious reactions, are those with history of anaphylaxis to latex, history of allergy to latex or rubber (urticaria, dermatitis, eye swelling, bronchospasm), history of atopy, history of multiple $(>5)$ surgical procedures: spina bifida, genitourinary anomalies (38).

Symptoms of latex allergy can range from mild urticarial to life-threatening events and death.

Exposure to latex can cause type I immunoglobulin (Ig) E mediated hypersensitivity reactions or more commonly an allergic contact dermatitis (type IV) (38). Clinical allergy to latex is indicated by repeated immediate reaction on latex exposure, including itching, hives, rhinoconjunctivitis, bronchospasm, angioedema, hypotension, and contact urticaria $(64,65)$. Also can be present CSF eosinophilia (66).

\section{Diagnosis and management}

Silicone:

In cases of recurrent malfunctions in 
which the origin remains unclear despite extensive routine investigations, it would be appropriate to consider diagnosis of silicone shunt allergy (44). Diagnosis of silicone allergy requires first ruling out other forms of shunt complications, such as infection and obstruction (44). Potential triggers other than silicone, such as intravenous or topical antibiotics like bacitracin, must also be examined (44). SPT and Immuno-CAP are sensitive and reliable diagnostic tools in detection of SB patients who are at high risk of developing allergic reactions to latex and should be used routinely to exclude the use of latex products in sensitized patients (25).

Jimenez et al. (10) recommended a battery of resources for evaluating silicone allergy such as assays for erythrocyte sedimentations rate, complement and immunoglobulin levels, fluorescent nuclear antibodies, ribonucleic proteins, extractable nuclear antibodies, and rheumatoid factor, tissues biopsy and human leukocyte antigen typing. They also recommended performing ELISAs for antisilicone IgG antibodies when available. Furthermore is recommended the pathological examination of the failed hardware.

The ELISA for antisilicone IgG antibodies was first described by Goldblum, et al (9). They demonstrated that ELISA is specific to symptomatically allergic patients and not just individuals exposed to silicone (44). Because of the multifaceted nature of the reaction to silicone in the rare instance that it does occur, treatment must involve complete removal of the silicone hardware:

- Shunt system can be removed without replacement if the patient can tolerate it (10).

- Shunt removal can be accompanied by a third ventriculostomy (this could be difficult in patients with complicated anatomy due to multiple surgeries) (44)

- Shunt-dependent patients can have the silicone-based hardware removed and replaced with non-silicone based hardware (e.g., polyurethane VP system, if this is selected, is recommended to consider long-term immunosuppression (10)).

In the case reported by Tangsinmankong et al. (26), they used a daily treatment with $2 \mathrm{mg} / \mathrm{kg}$ of methylprednisolone, and observed a reduction of the peripheral eosinophilia and slightly reduced CSF eosinophil counts. Pulse methylprednisolone, $15 \mathrm{mg} / \mathrm{kg}$, was associated with complete reduction of CSF eosinophils and prolonged VP shunt survival.

Latex:

A sensitive, specific, and safe skin test for latex sensitivity appears superior to in vitro testing for latex allergy. Age, number of surgical procedures, and the presence of positive allergen skin test responses are significantly correlated with latex sensitization. Age alone is significantly correlated with clinical allergy to latex (65). Testing for type I natural rubber latex allergy is through serum testing, such as RAST (radioallergosorbent test), which identifies what types of $\operatorname{IgE}$ proteins trigger allergic reactions.

Currently the only effective preventative strategy is latex avoidance (38). Some recommendations in the operating room are: Patient should be first on the list, latexfree theatre for at least 2 hours (ideally overnight) prior to case; all staff involved in patient care must be made aware of latex allergy status and warning signs should be posted outside the operating theatre; a 
latex-free trolley/box should be present with every case, which follows the patient from pre-assessment to postoperative care, and develop completely latex-free surgical areas (38).

\section{Conclusions}

Hydrocephalus shunt catheters cannot be termed "inert" or "biotolerated". Rather, they must be regarded as "bio-active" implants. The extensive reaction on silicated catheters can act as reference to estimate the biocompatibility of surface modifications (2).

SB patients with a history of repeated urologic procedures and a history of urticaria, especially male patients with such history, are most likely to develop allergy to latex products.

We conclude that pathological examination of shunt hardware is helpful in understanding noninfectious causes of shunt malfunction. We have identified a subgroup of patients who developed a hypersensitivity-like reaction around the shunt that in certain instances lead to shunt malfunction.

\section{Correspondence: \\ Dr. Luis Rafael Moscote-Salazar \\ University of Cartagena, \\ Cartagena de Indias, Colombia \\ e-mail:mineurocirujano@aol.com, \\ mineurocirujano@gmail.com}

\section{References}

1.Zhong Y, Bellamkonda RV. Biomaterials for the central nervous system. Journal of The Royal Society Interface. 2008 September 6, 2008; 5 (26): 957-75.

2.Eymann R, Kim YJ, Bohle RM, Antes S, Schmitt M, Menger $\mathrm{MD}$, et al. Microstructural alterations of silicone catheters in an animal experiment: histopathology and SEM findings. Acta neurochirurgica Supplement. 2012; 113: 87-90. PubMed PMID: 22116430. Epub 2011/11/26. eng.

3.Garton HJ, Piatt JH, Jr. Hydrocephalus. Pediatric clinics of North America. 2004 Apr; 51 (2): 305-25. PubMed PMID: 15062673. Epub 2004/04/06. eng.

4.Browd SR, Ragel BT, Gottfried ON, Kestle JR. Failure of cerebrospinal fluid shunts: part I: Obstruction and mechanical failure. Pediatric neurology. 2006 Feb; 34 (2): 83-92. PubMed PMID: 16458818. Epub 2006/02/07. eng.

5.de Aquino HB, Carelli EF, Borges Neto AG, Pereira CU. Nonfunctional abdominal complications of the distal catheter on the treatment of hydrocephalus: an inflammatory hypothesis? Experience with six cases. Child's nervous system: ChNS: official journal of the International Society for Pediatric Neurosurgery. 2006 Oct; 22 (10): 1225-30. PubMed PMID: 16525849. Epub 2006/03/10. eng.

6.Bousquet J, Flahault A, Vandenplas O, Ameille J, Duron JJ, Pecquet C, et al. Natural rubber latex allergy among health care workers: a systematic review of the evidence. The Journal of allergy and clinical immunology. 2006 Aug; 118 (2): 447-54. PubMed PMID: 16890771. Epub 2006/08/08. eng.

7.Gower DJ, Lewis JC, Kelly DL, Jr. Sterile shunt malfunction. A scanning electron microscopic perspective. J Neurosurg. 1984 Dec; 61 (6): 1079-84. PubMed PMID: 6502236. Epub 1984/12/01. eng.

8.Snow RB, Kossovsky N. Hypersensitivity reaction associated with sterile ventriculoperitoneal shunt malfunction. Surgical neurology. 1989 Mar; 31 (3): 20914. PubMed PMID: 2922665. Epub 1989/03/01. eng. 9.Goldblum RM, Pelley RP, O'Donell AA, Pyron D, Heggers JP. Antibodies to silicone elastomers and reactions to ventriculoperitoneal shunts. Lancet. 1992 Aug 29; 340 (8818): 510-3. PubMed PMID: 1354277. Epub 1992/08/29. eng.

10.Jimenez DF, Keating R, Goodrich JT. Silicone allergy in ventriculoperitoneal shunts. Child's nervous system: ChNS: official journal of the International Society for Pediatric Neurosurgery. 1994 Jan; 10 (1): 59-63. PubMed PMID: 8194064. Epub 1994/01/01. eng. 11.Brownlee JD, Brodkey JS, Schaefer IK. Colonic perforation by ventriculoperitoneal shunt tubing: a case of suspected silicone allergy. Surgical neurology. 1998 Jan; 49 (1): 21-4. PubMed PMID: 9428890. Epub 1998/01/16. eng.

12.Kashima ML, Tunkel DE, Cummings CW. Latex allergy: an update for the otolaryngologist. Archives of otolaryngology--head \& neck surgery. 2001 Apr; 127 (4): 442-6. PubMed PMID: 11296056. Epub 2001/05/05. eng.

13.Carver ED, Braude BM, Atkinson AR, Gold M. Anaphylaxis during insertion of a ventriculoperitoneal shunt. Anesthesiology. 2000 Aug; 93 (2): 578-9. PubMed PMID: 10910512. Epub 2000/07/26. eng. 14.Stern G. Uberempfindlichkeit gegen kautschuk als ursache von urticaria und quinckeschem ödem. Klin 
Wochenschr. 1927; 6: 1096-7.

15.Lavaud F, Prevost A, Cossart C, Guerin L, Bernard J, Kochman S. Allergy to latex, avocado pear, and banana: Evidence for a $30 \mathrm{kd}$ antigen in immunoblotting. Journal of Allergy and Clinical Immunology. 1995 2//; 95 (2): 557-64.

16.Nutter AF. Contact urticaria to rubber. The British journal of dermatology. 1979 Nov; 101 (5): 597-8. PubMed PMID: 518831. Epub 1979/11/01. eng.

17.Mertes PM, Laxenaire MC. Allergy and anaphylaxis in anaesthesia. Minerva anestesiologica. 2004 May; 70 (5): 285-91. PubMed PMID: 15181405. Epub 2004/06/08. eng.

18.Mertes PM, Tajima K, Regnier-Kimmoun MA, Lambert M, Iohom G, Gueant-Rodriguez RM, et al. Perioperative anaphylaxis. The Medical clinics of North America. 2010 Jul; 94 (4): 761-89, xi. PubMed PMID: 20609862. Epub 2010/07/09. eng.

19.Ellsworth PI, Merguerian PA, Klein RB, Rozycki AA. Evaluation and risk factors of latex allergy in spina bifida patients: is it preventable? J Urol. 1993 Aug; 150 (2 Pt 2): 691-3. PubMed PMID: 8326624. Epub 1993/08/01. eng.

20.Konz KR, Chia JK, Kurup VP, Resnick A, Kelly KJ, Fink JN. Comparison of latex hypersensitivity among patients with neurologic defects. The Journal of allergy and clinical immunology. 1995 May; 95 (5 Pt 1): 950-4. PubMed PMID: 7751515. Epub 1995/05/01. eng. 21.Kelly KJ, Pearson ML, Kurup VP, Havens PL, Byrd RS, Setlock MA, et al. A cluster of anaphylactic reactions in children with spina bifida during general anesthesia: epidemiologic features, risk factors, and latex hypersensitivity. The Journal of allergy and clinical immunology. 1994 Jul; 94 (1): 53-61. PubMed PMID: 8027499. Epub 1994/07/01. eng.

22.Schneck FX, Bellinger MF. The "innocent" cough or sneeze: a harbinger of serious latex allergy in children during bladder stimulation and urodynamic testing. J Urol. 1993 Aug; 150 (2 Pt 2): 687-90. PubMed PMID: 8326623. Epub 1993/08/01. eng.

23.Anaphylactic reactions during general anesthesia among pediatric patients--United States, January 1990January 1991. MMWR Morbidity and mortality weekly report. 1991 Jul 5; 40 (26): 437, 43. PubMed PMID: 2051973. Epub 1991/07/05. eng.

24.Nieto A, Estornell F, Mazón A, Reig C, Nieto A, García-Ibarra F. Allergy to latex in spina bifida: A multivariate study of associated factors in 100 consecutive patients. Journal of Allergy and Clinical Immunology. 1996 9//; 98 (3): 501-7.

25.Kattan H, Harfi H, Tipirneni P. Latex allergy in Saudi children with spina bifida. Allergy. 1999; 54 (1): 70-3. PubMed PMID: 5304452.

26. Tangsinmankong N, Nelson RP, Jr., Good RA. Glucocorticosteroid treatment for cerebrospinal fluid eosinophilia in a patient with ventriculoperitonial shunt. Annals of allergy, asthma \& immunology: official publication of the American College of Allergy, Asthma, \& Immunology. 1999 Oct; 83 (4): 341-2. PubMed PMID: 10541427. Epub 1999/10/29. eng.

27.Aichane A, Mahmal A, Bouayad Z. Allergie au latex chez le personnel de santé. Revue Française d'Allergologie et d'Immunologie Clinique. 1998 //; 38 (7, Supplement 1): S141-S4.

28. Ownby DR. A history of latex allergy. Journal of Allergy and Clinical Immunology. 2002 8//; 110 (2, Supplement): S27-S32.

29. Siler DJ, Cornish K, Hamilton RG. Absence of cross-reactivity of $\mathrm{IgE}$ antibodies from subjects allergic to Hevea brasiliensis latex with a new source of natural rubber latex from guayule (Parthenium argentatum). The Journal of allergy and clinical immunology. 1996 Nov; 98 (5 Pt 1): 895-902. PubMed PMID: 8939152. Epub 1996/11/01. eng.

30.Boxer MB, Grammer LC, Orfan N. Gutta-percha allergy in a health care worker with latex allergy. The Journal of allergy and clinical immunology. 1994 May; 93 (5): 943-4. PubMed PMID: 8182237. Epub 1994/05/01. eng.

31.Mavale-Manuel S, Paty E, Scheinmann P, de Blic J. Allergie au latex chez l'enfant. Archives de Pédiatrie. 2003 8//; 10 (8): 700-6.

32.Turjanmaa K. Natural rubber latex allergy: Clinical manifestations (including contact dermatitis) and diagnosis. Revue Française d'Allergologie et d'Immunologie Clinique. 1997 //; 37 (8): 1177-9.

33. Morales C, Basomba A, Carreira J, Sastre A. Anaphylaxis produced by rubber glove contact. Case reports and immunological identification of the antigens involved. Clinical and experimental allergy: journal of the British Society for Allergy and Clinical Immunology. 1989 Jul; 19 (4): 425-30. PubMed PMID: 2758356. Epub 1989/07/01. eng.

34.Levy DA, Charpin D, Pecquet C, Leynadier F, Vervloet D. Allergy to latex. Allergy. 1992 Dec; 47 (6): 579-87. PubMed PMID: 1285566. Epub 1992/12/01. eng.

35.Tomazic VJ, Withrow TJ, Fisher BR, Dillard SF. Latex-associated allergies and anaphylactic reactions. Clinical immunology and immunopathology. 1992 Aug; 64 (2): 89-97. PubMed PMID: 1643748. Epub 1992/08/01. eng.

36.Yeang HY, Hamilton RG, Bernstein DI, Arif SA, Chow KS, Loke YH, et al. Allergen concentration in natural rubber latex. Clinical and experimental allergy: journal of the British Society for Allergy and Clinical Immunology. 2006 Aug; 36 (8): 1078-86. PubMed PMID: 16911364. Epub 2006/08/17. eng.

37.Rougé P, Culerrier R, Campistron M, Granier C, Bienvenu F, Bienvenu J, et al. Allergenicity of Hev b 13, 
a major esterase allergen in natural rubber latex (Hevea brasiliensis) allergy, does not only depend on its carbohydrate moiety. Molecular Immunology. 2010 1//; 47 (4): 871-7.

38. Ng K, Fernandez E. Associated medical conditions in children. Anaesthesia \& Intensive Care Medicine. 2012 9//; 13 (9): 438-47.

39.Navarro M, Michiardi A, Castaño O, Planell JA. Biomaterials in orthopaedics. Journal of The Royal Society Interface. 2008 October 6, 2008; 5 (27): 113758.

40.Kunda LD, Stidham KR, Inserra MM, Roland PS, Franklin D, Roberson JB, Jr. Silicone allergy: A new cause for cochlear implant extrusion and its management. Otology \& neurotology: official publication of the American Otological Society, American Neurotology Society [and] European Academy of Otology and Neurotology. 2006 Dec; 27 (8): 1078-82. PubMed PMID: 17130797. Epub 2006/11/30. eng.

41.Agnew WF, Todd EM, Richmond H, Chronister WS. Biological evaluation of silicone rubber for surgical prosthesis. The Journal of surgical research. 1962 Nov; 2: 357-63. PubMed PMID: 14011239. Epub 1962/11/01. eng.

42.Del Bigio MR, Fedoroff S. Short-term response of brain tissue to cerebrospinal fluid shunts in vivo and in vitro. Journal of biomedical materials research. 1992 Aug; 26 (8): 979-87. PubMed PMID: 1429759. Epub 1992/08/01. eng.

43.Kalousdian S, Karlan MS, Williams MA. Silicone elastomer cerebrospinal fluid shunt systems. Council on Scientific Affairs, American Medical Association. Neurosurgery. 1998 Apr; 42 (4): 887-92. PubMed PMID: 9574653. Epub 1998/05/09. eng.

44.Hussain NS, Wang PP, James C, Carson BS, Avellino AM. Distal ventriculoperitoneal shunt failure caused by silicone allergy. Journal of Neurosurgery. 2005; 102 (3): 536-9. PubMed PMID: 15796391.

45.Kirwan L. Two cases of apparent silicone allergy. Plastic and reconstructive surgery. 1995 Jul; 96 (1): 2367. PubMed PMID: 7604119. Epub 1995/07/01. eng. 46.Peimer CA, Medige J, Eckert BS, Wright JR, Howard CS. Reactive synovitis after silicone arthroplasty. The Journal of hand surgery. 1986 Sep; 11 (5): 624-38. PubMed PMID: 3531304. Epub 1986/09/01. eng.

47.Kircher T. Silicone lymphadenopathy: a complication of silicone elastomer finger joint prostheses. Human pathology. 1980 May; 11 (3): 240-4. PubMed PMID: 6995270. Epub 1980/05/01. eng.

48.Kossovsky N, Heggers JP, Robson MC. Experimental demonstration of the immunogenicity of silicone-protein complexes. Journal of biomedical materials research. 1987 Sep; 21 (9): 1125-33. PubMed
PMID: 3667638. Epub 1987/09/01. eng.

49.Bowman BH, Schneider L, Barnett DR, Kurosky A, Goldblum RM. Novel urinary fragments from human basement membrane collagen. The Journal of biological chemistry. 1980 Oct 10; 255 (19): 9484-9. PubMed PMID: 7410437. Epub 1980/10/10. eng.

50.Varga J, Schumacher HR, Jimenez SA. Systemic sclerosis after augmentation mammoplasty with silicone implants. Annals of internal medicine. 1989 Sep 1; 111 (5): 377-83. PubMed PMID: 2669593. Epub 1989/09/01. eng.

51.Baldwin CM, Jr., Kaplan EN. Silicone-induced human adjuvant disease? Annals of plastic surgery. 1983 Apr; 10 (4): 270-3. PubMed PMID: 6847084. Epub 1983/04/01. eng.

52.Irving IM, Castilla P, Hall EG, Rickham PP. Tissue reaction to pure and impregnated silastic. Journal of pediatric surgery. 1971 Dec; 6 (6): 724-9. PubMed PMID: 5130591. Epub 1971/12/01. eng.

53.Heggers JP, Kossovsky N, Parsons RW, Robson MC, Pelley RP, Raine TJ. Biocompatibility of silicone implants. Annals of plastic surgery. 1983 Jul; 11 (1): 3845. PubMed PMID: 6614755. Epub 1983/07/01. eng. 54.Naim JO, Lanzafame RJ, van Oss CJ. The effect of silicone-gel on the immune response. Journal of biomaterials science Polymer edition. 1995; 7 (2): 12332. PubMed PMID: 7654627. Epub 1995/01/01. eng. 55.Hunsaker DH, Martin PJ. Allergic reaction to solid silicone implant in medial thyroplasty. Otolaryngology-head and neck surgery: official journal of American Academy of Otolaryngology-Head and Neck Surgery. 1995 Dec; 113 (6): 782-4. PubMed PMID: 7501393. Epub 1995/12/01. eng.

56.Frisch E. Technology of silicones in biomedical applications. LR R, editor. New York: CV Mosby; 1983. 57.Muramatsu Y, Sugino K, Kikuchi N, Sano G, Isobe $\mathrm{K}$, Takai Y, et al. [Human adjuvant disease which developed after silicone augumentation mammoplasty]. Nihon Kokyuki Gakkai zasshi $=$ the journal of the Japanese Respiratory Society. 2009 Mar; 47 (3): 237-41. PubMed PMID: 19348273. Epub 2009/04/08. jpn.

58.Carroll RP. Acute inflammatory reaction to silicone stents. Ophthalmic plastic and reconstructive surgery. 1989; 5 (1): 71. PubMed PMID: 2487201. Epub 1989/01/01. eng.

59.Jordan DR, Nerad JA. An acute inflammatory reaction to silicone stents. Ophthalmic plastic and reconstructive surgery. 1987; 3 (3): 147-50. PubMed PMID: 3154594. Epub 1987/01/01. eng.

60.Adegbite AB, Paine KW, Rozdilsky B. The role of neomembranes in formation of hematoma around Silastic dura substitute. Case report. J Neurosurg. 1983 Feb; 58 (2): 295-7. PubMed PMID: 6848694. Epub 1983/02/01. eng.

61.Sekhar LN, Moossy J, Guthkelch AN. 
Malfunctioning ventriculoperitoneal shunts. Clinical and pathological features. J Neurosurg. 1982 Mar; 56 (3): 411-6. PubMed PMID: 7057239. Epub 1982/03/01. eng.

62.Hashimoto M, Yokota A, Urasaki E, Tsujigami S, Shimono M. A case of abdominal CSF pseudocyst associated with silicone allergy. Child's nervous system: ChNS: official journal of the International Society for Pediatric Neurosurgery. 2004 Oct; 20 (10): 761-4. PubMed PMID: 14999512. Epub 2004/03/05. eng.

63.Kessler LA, Cheek WR. Eosinophilia of the cerebrospinal fluid of noninfectious origin: report of 2 cases. Neurology. 1959 May; 9 (5): 371-4. PubMed PMID: 13657297. Epub 1959/05/01. eng.
64.Niggemann B, Breiteneder H. Latex allergy in children. International archives of allergy and immunology. 2000 Feb; 121 (2): 98-107. PubMed PMID: 10705219. Epub 2000/03/08. eng.

65.Shah S, Cawley M, Gleeson R, O'Connor J, McGeady S. Latex allergy and latex sensitization in children and adolescents with meningomyelocele. The Journal of allergy and clinical immunology. 1998 Jun; 101 (6 Pt 1): 741-6. PubMed PMID: 9648700. Epub 1998/07/02. eng.

66.Niggemann B, Bauer A, Jendroska K, Wahn U. Latex allergy as a cause of eosinophilia in cerebrospinal fluid in a child with aventricular shunt. Journal of Allergy and Clinical Immunology. 1997 12//; 100 (6): 849-50. 